\title{
Optimization Study of Ultrasound-Assisted Polyphenol Extraction from Cocoa Powder and Utilization of Its Grounds Using Papain Solution
}

\author{
Noor Ariefandie Febrianto ${ }^{1 *}$ and Teguh Wahyudi ${ }^{1)}$ \\ ${ }^{1}$ Indonesian Coffee and Cocoa Research Institute, J1. PB. Sudirman 90, Jember Indonesia \\ ${ }^{*}$ Corresponding author: noor.ariefandie@gmail.com \\ Received: 4 February 2016 / accepted: 22 February 2016
}

\begin{abstract}
Today, utilization of cocoa powder has been derivatized not only used as food ingredients, but also expanding in its utilization in pharmaceutical. Utilization of cocoa powder mainly due to its advantageous and healthy polyphenol content which should be extracted from cocoa powder. Generally, this process will result in significant amounts of underutilized cocoa powder grounds. This research was carried out to evaluate utilization of ultrasound-assisted extraction method to extract antioxidative compounds from cocoa powder and to study the possibility of utilizing its grounds for antioxidative compounds by using papain solution. Extraction was carried out using different concentration of ethanol ranged from 53.8, 60, 80, 90 and $96.2 \%$ for $23.4,30,50,60$ and 66.2 minutes of extraction time. The evaluation was conducted using the analysis of total phenolic content and DPPH radical scavenging activity. Further, freshly prepared papain was used in different concentration ranged from 2,4 , and $6 \%$ to incubate the cocoa grounds for 2, 3, and 4 hours. The obtained cocoa hydrolysate solution was analyzed for its protein content and its antioxidant activity. The optimization study of the process was carried out using response surface methodology. This study shows that the use of $60 \%$ ethanol for 30 min extraction was optimum method to extract phenolic compounds from cocoa powder. On the other hand, the use of papain solution revealed that the underutilized cocoa grounds can be potentially used as the source of protein and antioxidant.
\end{abstract}

Keywords: ultrasound-extraction, papain, cocoa hydrolysate, antioxidant, polyphenol

\section{INTRODUCTION}

Cocoa, undoubtedly, is one of the most important ingredients in food industries, especially in confectionaries. Cocoa is usually be processed into food products such as chocolate bar, chocolate candy and beverages. In addition to its high appreciation for its delicacy, cocoa has been widely known to give health benefits due to high content of phenolic compounds. Flavan-3-ol, anthocyanin and procyanidine are major polyphenol compounds in cocoa where catechins and epicatechins are the main components of procyanidine (Weisburger, 2005). Incorporation of polyphenols in human foods will not only preserves their wholesome, but also reduces the risk of developing health problems such as atherosclerosis and cancer (Ames, 1983; Namiki, 1990; Ramarathnarn et al., 1995). 
The extraction of polyphenol compound from cocoa has been reported previously by Misnawi (2003) who carried out the extraction by maceration for 24 hours, which is becoming a commonly used method for extracting polyphenol. Recently, ultrasound-assisted extraction method has gained more attention due to its ability to improve the performance of solvent extraction (Armenta et al., 2006). This method was reported to give a better result despite it was operated at low temperature for short time. Ultrasound-assisted method has been found to be able to extract corn carotenoids (Ye et al., 2011), protein from rice bran (Chittapalo \& Noomhorm, 2009), carotenoids and chlorophylls from Chlorella vulgaris (Cha et al., 2010) and polyphenols from tobacco (Gu et al., 2005).

In accordance with the increasing trend of cocoa polyphenol utilization as pharmaceutical products, the utilizing of its by-product should be put into consideration. Cocoa grounds obtained from cocoa polyphenol extraction are considered as underutilized products due to its limitation of usage despite containing high nutritional content. Currently, conversion of by-products into hydrolysatebased products is more interested. Protein hydrolysate is one of the popular hydrolysatebased product which can be produced from protein-contained by-product. Protein hydrolysates are defined as products of protein breakdown into smaller peptides of various sizes by means of chemical or biological process (Pasupuleti \& Braun, 2010). Compared to other sources of protein hydrolysate such as fish, soy and whey, the protein of cocoa powder is low. However, previous report showed that the protein hydrolysate could be successfully produced from low protein content materials such as rice bran (Hamada, 2000), sweet potato (Zhang et al., 2012) and Jatropa curcas (Gallegos-Tintore et al., 2011).
Protein hydrolysate is commonly produced by means of acid or base hydrolysis and enzymatic hydrolysis. Pasupuleti \& Braun (2010) reported that the use of enzymes offered significant advantages compared to acid or base-based processes. Enzymatic hydrolysis require a relatively small amount of enzymes that can be easily deactivated and relatively easily-controlled conditions of hydrolysis (temperature and $\mathrm{pH}$ ). Papain is one of the protease enzymes that can be easily found and produced in Indonesia. The use of raw papain to produce protein hydrolysate will be beneficial since it can reduce production cost and more available. This research aimed to study the utilization of ultrasound-assisted extraction method to extract antioxidative compounds from cocoa powder and to study the possibility of utilizing its grounds for its antioxidative compound by the use of the papain solution.

\section{MATERIALS AND METHODS}

Cocoa powder was obtained from cocoa processing unit in Indonesian Coffee and Cacao Research Institute (ICCRI), Jember, East Java. The cocoa powder used in this experiment was the powder that can not be shieved during the production of fine cocoa powder. Papain enzyme was prepared independently utilizing local papaya planted in Kaliwining Experimental Station of ICCRI, Jember, East Java. The research was conducted in Post-harvest Laboratory of ICCRI, Jember.

\section{Papain Crude Extract Preparation}

Papain crude extract was isolated from unripe fruits of papaya (Carica papaya L.). Fresh latex of papaya was collected from locally grown papaya in Kaliwining Experimental Station. The collection was carried out by making a longitudinal incisions on the unripe 
fruits using clean stainless steel knife. The latex that came out from the fruits was then collected in clean beaker glasses and immediately stored on the screw capped bottles, avoided from direct sunlight. The collection time of papaya latex was limited daily only from 8 a.m. to 10 a.m. Collected papaya latex was then stored in $4^{\circ} \mathrm{C}$ until powdering process. The collected latex from papaya was then diluted with small amount of distilled water and added with natrium metabisulfit for approximately $0.7 \%$ of its total weight. The solution was then homogenized using a magnetic stirrer until a homogenized whitish milk-like solution was obtained. The solution was then poured into petri-dishes for drying process carried out in an oven at the temperature of $60^{\circ} \mathrm{C}$ for 5 to 6 hours. Dried papain was then hand milled and stored in screw capped, light-tight bottles and stored in $4^{\circ} \mathrm{C}$ until being used. In the preliminary analysis, it was found that the activity of the enzyme was $1,080 \mathrm{MCU} / \mathrm{g}$.

\section{Ultrasound-Assisted Polyphenol Extraction}

The ultrasound-assisted polyphenol extraction was carried out using 5 different concentrations of ethanol, ranged from 53.8, $60,80,90.0$, and $96.2 \%$. Ultrasonic LC $30 \mathrm{H}$ was used for the extraction with the extraction time varied from 23.4, 30.5, 60.0 and 66.2 minutes. The ratio between the substrate (cocoa powder) and solvent was 1 to $10(1 \mathrm{~g}$ of cocoa powder with $10 \mathrm{~mL}$ of ethanol). The solution obtained from the extraction was then filtered and stored in screw capped, lighttight bottles and stored in $4^{\circ} \mathrm{C}$ until being analyzed.

\section{Preparation and Characterization of Cocoa Grounds}

The cocoa ground used for hydrolysis was previously prepared by extracting the cocoa powder using ultrasound-assisted extraction in its optimum condition found in this study. After the precipitate was obtained, the cocoa grounds were then dried and stored in a tight container until used. The characterization of cocoa grounds was done by analyzing the variables of moisture content, ash content, fat content and protein content. The analysis was carried out using the method listed in Indonesian National Standard (SNI 3747-2013) (BSN, 2014) and Kjeldahl method for protein analysis.

\section{Hydrolysis of Cocoa Powder in Papain Solution System}

Hydrolysis of cocoa grounds was carried out using water diluted-papain powder. Prior to the addition of enzymes solution, the cocoa ground was diluted with distilled water in the ratio of cocoa ground to water was 1 to 4 . The cocoa ground solution was then added either using $0.5 \mathrm{~N}$ sodium hydroxide or $0.5 \mathrm{~N}$ hydrochloric acid to adjust the $\mathrm{pH}$ at the point of 6.5 (optimum $\mathrm{pH}$ of papain). The solution was homogenized and $5 \mathrm{~mL}$ of the solution was transferred into a test tube. The papain enzyme solution was then added in various concentrations as much as 2, 4, $6 \%$ of cocoa ground weight. The mixed solution was incubated in water bath set at the temperature of $70^{\circ} \mathrm{C}$ for 2 , 3 , and 4 hours. Every 30 minutes, the mixtures were stirred to homogenize. After the defined time of hydrolysis was reached, the test tube was then dipped in boiling water for 10 to 15 minutes to terminate the hydrolysis process by stopping the proteolytic activity of papain enzyme. The solution obtained was then centrifuged at $3500 \mathrm{rpm}$ for 15 minutes and then separated between supernatant and precipitate. The supernatant was filtered using filter paper (Whatman, grade 93) until solid-free solution was obtained. This solution was stored in a screw capped bottle and stored in $4^{\circ} \mathrm{C}$ until analyzed. This solution obtained from 
the hydrolysis process was then referred as cocoa hydrolysate.

\section{Total Phenolic Content Analysis}

Analysis of total phenolic content (TPC) was carried out using the modified method of Szydlowska-Czerniak (2008) with slight modification. As much as $0.1 \mathrm{~mL}$ of extract obtained from ultrasound-assisted extraction was added with $0.5 \mathrm{~mL}$ Folin Ciocalteu reagent and then vortexed and rested for three minutes. One milliliter of saturated $\mathrm{Na}_{2} \mathrm{CO}_{3}$ was added and the solution stored for one hour in a dark container. The absorbance of the solution was then measured with three replications using a spectrophotometer (Perkin Elmer Lambda $35 \mathrm{UV} / \mathrm{Vis}$ Spectrophotometer) using a wavelength of $725 \mathrm{~nm}$. The standard curve was prepared by using catechin ranged from 0.03 to $0.20 \mathrm{mg}$ catechin.

\section{Protein Content Analysis}

Protein content of the protein hydrolysate solution was measured using the method of Lowry (Sudarmadji et al., 1997). The Lowry A reagent was prepared by diluting $2 \mathrm{~g}$ of $\mathrm{Na}_{2} \mathrm{CO}_{3}$ in $100 \mathrm{~mL}$ of $0.1 \mathrm{~N} \mathrm{NaOH}$. Lowry $\mathrm{B}$ reagent was prepared by diluting $0.5 \mathrm{~g}$ of $\mathrm{CuSO}_{4} .5 \mathrm{H}_{2} \mathrm{O}$ in $100 \mathrm{~mL}$ of $1 \%$ sodium potassium tartarate. The Lowry $\mathrm{C}$ reagent was prepared freshly prior to analysis by mixing $50 \mathrm{~mL}$ of Lowry $\mathrm{A}+1 \mathrm{~mL}$ of Lowry B. As much as $0.1 \mathrm{~mL}$ of hydrolysate solution was added to $8 \mathrm{~mL}$ of Lowry $\mathrm{C}$ reagent. The solution was allowed to stand for 10 minutes prior to the addition of $1 \mathrm{~mL}$ Follin Ciocalteu reagent and then homogenized. The absorbance of the solution was measured using a spectrophotometer (Perkin Elmer Lambda 35 UV/Vis Spectrophotometer) using a wavelength of $600 \mathrm{~nm}$. The standard curve was prepared by using Bovine serum albumin in the concentration range of 0 to $3 \mathrm{mg} / \mathrm{mL}$.

\section{DPPH Radical Scavenging Activity}

Radical scavenging activity (RSA) analysis was performed based on the activity of the 2,2-diphenyl-1-picrylhydrazyl (DPPH). This analysis was carried out using the method of Kalantzakis et al. (2006) with some modifications. The methanolic extract was prepared by diluting $0.1 \mathrm{~mL}$ of sample with $4.9 \mathrm{~mL}$ methanol. As much as $0.1 \mathrm{~mL}$ of the methanolic solution was placed into a test tube and mixed with $4.9 \mathrm{~mL} \mathrm{DPPH}$ solution ( $0.1 \mathrm{mM}$ in methanol) then shaken vigorously. The solution was placed in a dark place for 30 minutes. The absorbance of the sample mixture was measured with three replications at $517 \mathrm{~nm}$ using a spectrophotometer (Perkin Elmer Lambda 35 $\mathrm{UV} / \mathrm{V}$ is Spectrophotometer). RSA result was presented as 6-hydroxy-2,5,7,8tetramethyl-chroman-2-carboxylic acid (trolox) equivalent.

\section{Statistical Analysis and Optimization}

The experiment was carried out by two variables (three levels of each variable), face centered central composite design with five replications at the center points. The levels of variable were coded as $(-1.44,-1,0,+1$, $+1.44)$ for extraction study and $(-1,0,+1$, for hydrolysis study. The independent variables were enzyme concentration (A), and hydrolysis time (B). Statistical analysis was carried out using Design Expert ${ }^{\circledR}$ version 7.0.0 (Stat-Ease, Inc., Minneapolis, MN, USA). The model was performed at the $5 \%$ significance level. The response function $\mathrm{Y}$ for all responses was fitted to a second-degree polynomial using equation:

$$
\begin{aligned}
\mathrm{Y}= & \mathrm{b} 0+\mathrm{b} 1 \mathrm{~A}+\mathrm{b} 2 \mathrm{~B}+\mathrm{b} 12 \mathrm{AB}+\mathrm{b} 11 \mathrm{~A}^{2}+ \\
& \mathrm{b} 22 \mathrm{~B}^{2}+\varepsilon
\end{aligned}
$$

The linear, quadratic, and interaction effects were represented along with the 
coefficient (b0) by b1, b2, (linear effects), b12 (interaction effects), thus b11, and b22 for quadratic effects. The optimum condition for the chosen desired goal was decided using Myers and Montgomery desirability method contained in the software in purpose to maximize TPC and antioxidant activity of the solution obtained from ultrasound-assisted extraction and the protein content and DPPH RSA for the solution obtained from hydrolysis using papain enzyme. Pearson correlation analysis was done using SPSS software ver. 17.0 (IBM).

\section{RESULTS AND DISCUSSION}

\section{Ultrasound-Assisted Polyphenol Extraction}

The result of TPC analysis was shown in Table 1 . The recovery of phenolic content of the extracts varied from 5.6 to 29.53 eq. $\mathrm{mg}$ catechin/g powder. On the other hand, the antioxidant activity of the extracts was in the range of 0.747 to $19.933 \mathrm{TE} \mathrm{mM} / \mathrm{mL}$ extract. Generally, the antioxidant activity of the extract was in positive correlation with the phenolic content in the extracts. Pearson correlation analysis showed that the phenolic content extracted from cocoa powders had a significant positive correlation with DPPH $(r=0.914, p<0.05)$. Ho (1992) previously mentioned that the phenolic compounds were recognized by their ability to act as antioxidant due to its high antioxidative ability. Pratt (1992) also previously mentioned that phenolic compound such as flavonoids (flavones, catechins, flavanones, flavanols etc.) were typical compounds that possess antioxidant activity. Hence, it is reasonable that the TPC and DPPH RSA of the extract was significantly correlated since flavan-3-ol, catechins and epicatechins are the main phenolic components in cocoa (Weisburger, 2005).

The responses of TPC and DPPH RSA of cocoa extract were found to follow the quadratic mathematic model (Table 2). According to Herpandi et al. (2003), significant quadratic model means that addition of quadratic terms significantly improve the model adequacy and suitable for the respective response. Furthermore, the quadratic model was supported by the high value of $\mathrm{R}^{2}$ and adjusted $\mathrm{R}^{2}$ that were more than 0.80 . The high value of coefficient of determination $(>0.80)$ showed that non-significant term was already excluded from the equation and the model is adequate

Table 1. TPC and antioxidant activity on ultrasound-assisted's extract solution in various concentrations of ethanol and extraction time

\begin{tabular}{|c|c|c|c|c|c|}
\hline \multicolumn{2}{|c|}{ Ethanol concentration $(\%)$} & \multicolumn{2}{|c|}{ Extraction time (min) } & \multirow{2}{*}{$\begin{array}{l}\text { TPC eq. mg catechin/ } \\
\text { g powder }\end{array}$} & \multirow{2}{*}{ DPPH RSATE $\mathrm{mM} / \mathrm{mL}$} \\
\hline Code level a & Actual level A & Code level $\mathrm{b}$ & Actual level B & & \\
\hline 0 & 75.00 & -1.414 & 23.79 & 20.48 & 8.66 \\
\hline-1 & 60.00 & -1 & 30.00 & 29.53 & 17.39 \\
\hline 1 & 90.00 & -1 & 30.00 & 8.93 & 3.76 \\
\hline-1.414 & 53.79 & 0 & 45.00 & 29.01 & 16.52 \\
\hline 0 & 75.00 & 0 & 45.00 & 20.13 & 14.58 \\
\hline 0 & 75.00 & 0 & 45.00 & 22.47 & 18.96 \\
\hline 0 & 75.00 & 0 & 45.00 & 22.30 & 16.10 \\
\hline 0 & 75.00 & 0 & 45.00 & 21.74 & 17.53 \\
\hline 0 & 75.00 & 0 & 45.00 & 22.11 & 15.34 \\
\hline 1.414 & 96.21 & 0 & 45.00 & 5.60 & 0.75 \\
\hline-1 & 60.00 & 1 & 60.00 & 27.57 & 17.95 \\
\hline 1 & 90.00 & 1 & 60.00 & 14.45 & 7.27 \\
\hline 0 & 75.00 & 1.414 & 66.21 & 29.45 & 19.93 \\
\hline
\end{tabular}

Notes: Figures are means of three replications. 
to present the responses (Little \& Hills, 1978; Koochecki et al., 2009). Both TPC and DPPH RSA responses showed good coefficients of determination $\left(\mathrm{R}^{2}\right)$, which are 0.977 and 0.9581 , respectively and followed by close value of adjusted $\mathrm{R}^{2}$. Since both of the responses showed that the quadratic models were fit and sufficient to be used for the optimization.

Ethanol concentration, extraction time and their interactions were significant factors of TPC responses. As the increase of ethanol concentration, the recovery of phenolic compounds from cocoa powder became more difficult. However, the recovery of phenolic compounds increased as the longer extraction time in high ethanol concentration (Figure 1). This result was in agreement with the report of Chen et al. (2012) which found that high concentration of ethanol (95\%) showed less performance to extract the phenolic compounds from areca husk compared to low concentration of ethanol $(40-60 \%)$ in the ultrasound assisted extraction. Yu et al. (2002) previously reported the addition of a certain amount of water in ethanol could improve the efficiency of phenolic compound extraction compared to pure ethanol. Further, Rostagno et al. (2003) and Proestos \& Komaitis (2006) also confirmed that the use of ethanol in 40 to $60 \%$ concentration could give optimum performance. High concentration of ethanol performed less effective to extract the phenolic compounds, since concurrent lipid and phenolic extraction could occur due to the polarity of ethanol in substrate with high content of lipid such as in the cocoa powder (Chen et al., 2012; Wang et al., 2008).

Table 2. Analysis of variance TPC and DPPH antioxidant activity of the cocoa hydrolysate according to response surface methodology

\begin{tabular}{lcc}
\hline Parameter & TPC & DPPH \\
\hline Model & Quadratic & Quadratic \\
Lack of fit & Not significant $(<0.05)$ & Not significant $(<0.05)$ \\
$\mathrm{R}^{2}$ & 0.977 & 0.959 \\
Adjusted $\mathrm{R}^{2}$ & 0.960 & 0.929 \\
Equation (actual level) & $\mathrm{Y}=35.7367+0.72 \mathrm{~A}-1.03 \mathrm{~B}+$ & $\mathrm{Y}=-53.843+2.333 \mathrm{~A}-0.206 \mathrm{~B}-0.019 \mathrm{~A}^{2}$ \\
& $0.00832 \mathrm{AB}-0.01 \mathrm{~A}^{2}$ & $\mathrm{~A}, \mathrm{~B}, \mathrm{~A}^{2}$ \\
\hline
\end{tabular}
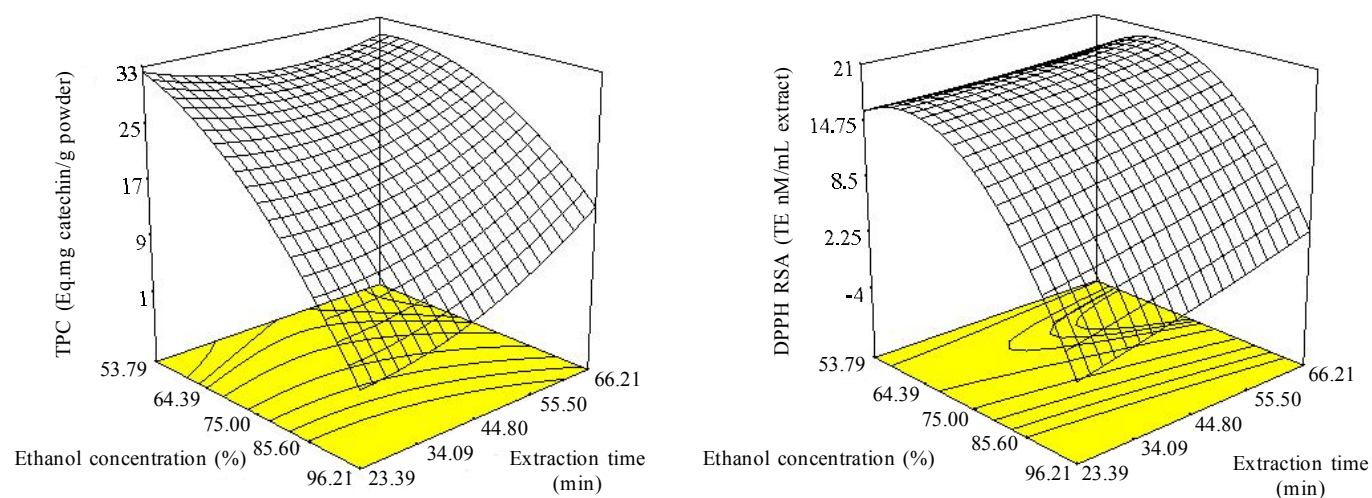

Figure 1. Response surface of the effect of ethanol concentration and extraction time on TPC recovery (left) and on DPPH antioxidant activity (right) of cocoa extract 
The DPPH RSA responses of the extract showed that ethanol concentration and extraction time could be significant factor in the extraction of phenolic compounds using ultrasound-assisted method. Since it is in significant correlation with TPC responses, this result has shown that ultrasound-assisted extraction method could effectively extract antioxidative phenolic compounds from cocoa powder. This optimization study showed that low concentration ethanol in a range between 53.8 to $75 \%$ was sufficient to be used in ultrasound-assisted extraction. Further, the study also revealed that the extraction process using low concentration of ethanol only needed about 23.4 to 30 minutes, which was significantly more efficient compared to an old maceration method that could consume around 24 hours process.

\section{Hydrolysis of Cocoa Grounds in Papain Solution System}

The proximate analysis carried out on cocoa ground sample revealed that the cocoa grounds contained relatively high protein content $(21.8 \%)$ and fat content (35.7\%) (Table 3). This result was in agreement with previous calculation (Febrianto, 2013) cocoa powder defatted using hydraulic extraction resulted in protein content as much as $20 \%$ of its dry bases. The protein content of cocoa grounds is considered as relatively high compared to other commodity such as palm kernel cake (17.6\%) which has been successfully transformed into protein hydrolysate as reported by Zarei et al. (2012).

The responses of protein content and antioxidant activity of cocoa hydrolysate were found to follow a quadratic mathematic model (Table 4). Both protein content and DPPH responses showed good coefficient of determination $\left(\mathrm{R}^{2}\right)$, which were 0.95 and 0.92 , respectively and followed by close value of adjusted $\mathrm{R}^{2}$. According to the result of protein content analysis based on Lowry, the protein content of the cocoa hydrolysate solution was in the range of $6.35 \mathrm{mg} / \mathrm{mL}$ to $10.42 \mathrm{mg} / \mathrm{mL}$. On the other hand, the antioxidant activity of the cocoa hydrolysate solution was in the range of 1.65 to $3.65 \mathrm{TE}$ $\mathrm{mM} / \mathrm{mL}$ (Table 5). Incubation time, enzyme concentration and interaction between incubation time and enzyme concentration was found to be significant factors of protein content responses. The protein content of cocoa hydrolysate was increasing as the increase of incubation time and enzyme concentration (Figure 3). The increasing of protein content in the solution was the result of amino acid liberation into hydrolysate solution due to hydrolysis activity of papain. As mentioned previously by Wu et al. (1998), the use of papain enzyme was reported to produce water soluble amino acid/peptide that significantly increases the solubility of the hydrolysate. Highest responses of protein content were found in the $6 \%$ enzyme concentration and four hours incubation resulted in $10.42 \mathrm{mg} /$ $\mathrm{mL}$ cocoa hydrolysate or approximately $39.92 \%$ protein recovery of cocoa grounds.

On the other hand, DPPH antioxidant activity responses were significantly affected by incubation time and enzyme concentration. The antioxidant activity of cocoa hydrolysate was decreasing as the increase of incubation time and enzyme concentration (Figure 2). Highest responses of antioxidant activity were found in the $2 \%$ enzyme concentration and three hours incubation which resulted in $3.65 \mathrm{mM}$ $\mathrm{TE} / \mathrm{mL}$ cocoa hydrolysate. As mentioned by Jun et al. (2004), antioxidative activity of protein hydrolysate depends on the protease enzymes used and the hydrolysis condition applied. Based on the report of Korhonen \& Pihlanto (2003) and Shahidi \& Zhong (2008), bioactive peptides that posses antioxidant activity can be released during enzymatic hydrolysis. Je et al. $(2005 ; 2007)$ also reported that hydrolyzed proteins from animal and 
Table 3. The characteristic of cocoa powder used in the research

\begin{tabular}{lc}
\hline Parameter & Value (db) \\
\hline Moisture content & $6.6 \%$ \\
Ash content & $4.6 \%$ \\
Fat content (hydrolysis + soxhlet method) & $35.7 \%$ \\
Protein content & $21.7 \%$ \\
\hline
\end{tabular}

Note: $\mathrm{db}=$ dry bases.

Table 4. Experimental design and analysis result of protein content and antioxidant activity on cocoa hydrolysate solution

\begin{tabular}{|c|c|c|c|c|c|}
\hline \multicolumn{2}{|c|}{ Enzyme concentration (\%) } & \multicolumn{2}{|c|}{ Hydrolysis time (hours) } & \multirow{2}{*}{$\begin{array}{l}\text { Protein content } \\
\qquad(\mathrm{mg} / \mathrm{mL})\end{array}$} & \multirow{2}{*}{$\begin{array}{l}\text { DPPH RSATE } \\
(\mathrm{mM} / \mathrm{mL})\end{array}$} \\
\hline Code level a & Actual level A & Code level $\mathrm{b}$ & Actual level B & & \\
\hline-1 & 2.00 & -1 & 2.00 & 6.35 & 3.59 \\
\hline 0 & 4.00 & -1 & 2.00 & 7.55 & 3.16 \\
\hline 1 & 6.00 & -1 & 2.00 & 7.62 & 2.42 \\
\hline-1 & 2.00 & 0 & 3.00 & 7.02 & 3.65 \\
\hline 0 & 4.00 & 0 & 3.00 & 7.90 & 2.58 \\
\hline 0 & 4.00 & 0 & 3.00 & 8.23 & 2.78 \\
\hline 0 & 4.00 & 0 & 3.00 & 8.41 & 2.43 \\
\hline 0 & 4.00 & 0 & 3.00 & 8.00 & 2.97 \\
\hline 0 & 4.00 & 0 & 3.00 & 8.30 & 2.88 \\
\hline 1 & 6.00 & 0 & 3.00 & 8.72 & 2.24 \\
\hline-1 & 2.00 & 1 & 4.00 & 7.36 & 2.84 \\
\hline 0 & 4.00 & 1 & 4.00 & 8.62 & 2.19 \\
\hline 1 & 6.00 & 1 & 4.00 & 10.42 & 1.65 \\
\hline
\end{tabular}

Table 5. Analysis of variance of protein content and DPPH antioxidant activity of the cocoa hydrolysate according to response surface methodology

\begin{tabular}{lcc}
\hline Parameter & Protein content & DPPH \\
\hline Model & Quadratic & Quadratic \\
Lack of fit & Not significant $(<0.05)$ & Not significant $(<0.05)$ \\
$\mathrm{R}^{2}$ & 0.9565 & 0.9264 \\
Adjusted $\mathrm{R}^{2}$ & 0.9255 & 0.8738 \\
Equation (actual level) & $\mathrm{Y}=5.38776+0.282 \mathrm{~A}-0.0196 \mathrm{~B}+0.22375 \mathrm{AB}$ & $\mathrm{Y}=3.9599-0.484 \mathrm{~A}+0.680 \mathrm{~B}$ \\
Significant factor & $\mathrm{A}, \mathrm{B}, \mathrm{AB}$ & $\mathrm{A}, \mathrm{B}$ \\
\hline
\end{tabular}
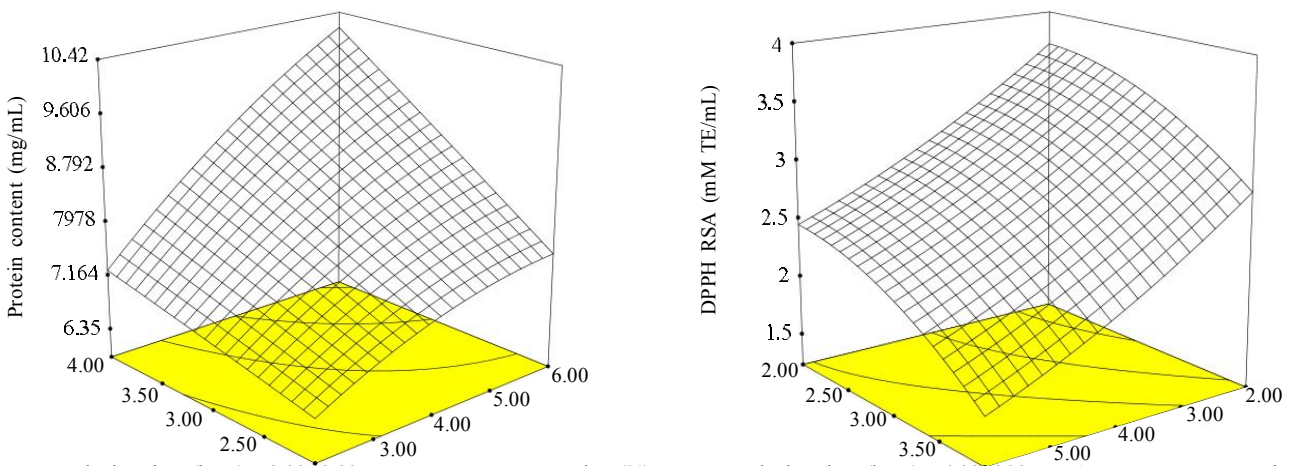

B: Incubation time (hour) $\quad 2.002 .00 \quad$ A: Enzyme concentration (\%)

B: Incubation time (hour) $4.006 .00 \quad$ A: Enzyme concentration (\%)

Figure 2. Response surface of the effect of incubation time and enzyme concentration on protein content of cocoa hydrolysate (left), and DPPH antioxidant activity of cocoa hydrolysate (right) 
plant sources have been found to possess antioxidant activity. Several amino acids, such as tyrosine, methionine, histidine, lysine and tryptophan, are generally thought to have antioxidant properties.

Pearson correlation analysis showed that protein content of cocoa hydrolysate had a significant contrary correlation with DPPH results $(r=0.88, p<0.05)$, which indicated that the increase in soluble protein content in cocoa hydrolysate was not necessarily improve its antioxidant activity. Wu et al. (2003) mentioned that hydrolysate with the size of 1400 Da possesed higher antioxidant activity than smaller molecular weight. Further, Herpandi (2013) also mentioned that the skipjack tuna hydrolysate, which was dominated with peptide in the range of molecular weight between 1000 to $3000 \mathrm{Da}$ possessed higher antioxidant activity comparable to hydrolysate which is dominated with low molecular weight $(<1000 \mathrm{Da})$. Based on Rawlings et al. (2007) and Graf et al. (2004), papain is categorized as endopeptidase, the type of protease that hydrolyze alpha-peptide bonds in polypeptide chain and tending to act away from the $\mathrm{N}$-terminus or C-terminus. This type of enzymes tends to produce high molecular weight peptide rather than amino acid or oligopeptides (Chapot-Chartier, 2004; Dudley $\&$ Steele, 2004). Ideally, the digestion of food proteins is usually initiated by endopeptidases to generate new $\mathrm{N}$ - and $\mathrm{C}$ termini, and then it is continued by exopeptidases which utilize that product as a substrate to complete the proteolytic process resulting in amino acids or low molecular oligopeptides (Rawlings et al., 2007). However, Herpandi (2013), Foh et al. (2010) and Ovissipour et al. (2011) also found that the hydrolysis using endoprotease enzymes could also produce low molecular weight protein if carried out on longer time of hydrolysis. Hence, it is reasonable that the longer the hydrolysis time, the DPPH RSA responses were decreased, since the extensive hydrolysis process tend to hydrolyze previously liberated peptide into smaller and lower molecular weight compound that possess lower antioxidant activity.

\section{CONCLUSION}

The extraction of antioxidative phenolic compounds from cocoa powder has been successfully carried out by ultrasound-assisted extraction method. This method has been found to be able to recover high content of antioxidative phenolic compounds in a relatively short time by using a low concentration of ethanol solvent. Moreover, the underutilized cocoa grounds resulted from the extraction could be utilized as the source of water soluble antioxidative protein by means of hydrolysis using papain enzymes.

\section{ACKNOWLEDGEMENT}

The authors would like to express his gratitude to the Indonesian Agency for Agricultural Research and Development for the support in this research under the grant number 128.1/LB.620/I.4/2/2014 and an anonymous reviewers for their contribution to the perfection of this paper.

\section{REFFERENCES}

Ames, B.N. (1983). Dietary carcinogens and anticarcinogens: Oxygen radicals and degenerative diseases. Science, 221, 1256-1264.

Armenta, R.E.; A. Burja; H. Radianingtyas \& C.J. Barrow (2006). Critical assessment of various techniques for the extraction of carotenoids and co-enzyme $\mathrm{Q}(10)$ from the thraustochytrid strain ONC-T18. Journal of Agricultural and Food Chemistry, 54, 9752-9758. 
BSN (2014). SNI 3747-2013. Kakao Bubuk. Badan Standarisasi Nasional, Jakarta, Indonesia

Cha, K.H.; H.J. Lee; S.Y. Koo; D.G. Song \& C.H. Pan (2010). Optimization of pressurized liquid extraction of carotenoids and chlorophylls from Chlorella vulgaris. Journal of Agricultural and Food Chemistry, 58, 793-797.

Chapot-Chartier; M.P. \& M.Y. Mistou (2004). PepC aminopeptidase of lactic acid bacteria. p. 1202-1204. In: A.J. Barrett, N.D. Rawlings \& J.F. Woessner (Eds). Handbook of Proteolytic Enzymes, Elsevier, London.

Chen, W.J.; Y. Huang; J. Qi, M. Tang; Y. Zhoeng; S. Zhao \& L. Chen (2012). Optimization of ultrasound-assisted extraction of phenolic compounds from areca husk. Journal of Food Processing and Preservation, 38, 90-96.

Chittapalo, T. \& A. Noomhorm (2009). Ultrasound assisted alkali extraction of protein from defatted rice bran and properties of the protein concentrates. International Journal of Food Science and Technology, 44, 1843-1849.

Dudley, E.G. \& J.L. Steele (2004). Dipeptidase DA. p. 2052-2053. In: A.J. Barrett, N.D. Rawlings \& J.F. Woessner (Eds). Handbook of Proteolytic Enzymes, Elsevier, London.

Febrianto, N.A. (2013). Hidrolisat protein asal bungkil kakao dan ampas kopi. Warta Pusat Penelitian Kopi dan Kakao Indonesia, 25, 20-23.

Foh, M.B.K.; I. Amadou; M.B. Foh; M.T. Kamara \& W. Xia (2010). Functionality and antioxidant properties of tilapia (Oreochromis niloticus) as influenced by the degree of hydrolysis. International Journal of Molecular Sciences, 11, 1851-1869.

Gallegos-Tintore, S.; C.T. Fuentes; J.S. Feria, M. Alaiz; J.G. Calle; A.L.M. Ayala; L.C. Guerrero \& J. Vioque (2011). Anti- oxidant and chelating activity of Jatropa curcas L. protein hydrolysates. Journal of the Science of Food and Agriculture, 91, 1618-1624.

Graf, L.; L. Szilagy \& I. Venekei (2004). Chymotrypsin. p. 1495-1501. In: A.J. Barrett; N.D. Rawlings \& J.F. Woessner (Eds.). Handbook of Proteolytic Enzymes, Elsevier, London.

Gu, X.; J. Cai; X. Zhu \& Q. Su (2005). Dynamic ultrasound-assisted extraction of polyphenols in tobacco. Journal of Separation Science, 28, 2477-2481.

Hamada, J.S. (2000). Characterization and functional properties of rice bran proteins modified by commercial exoproteases and endoproteases. Journal of Food Science, 65, 305-310.

Herpandi (2013). Enzymatic Hydrolysis of Tuna By Products: Physico-chemical Characteristics, Digestibility and Antioxidative Properties of the Hydrolysate. PhD thesis. Universiti Sains Malaysia. Penang, Malaysia.

Ho, C.T. (1992). Phenolic compounds in foods. p. 2-7. In: M.T. Huang; C.T. Ho \& C.Y. Lee (Eds.). Phenolic Compounds in Food and Their Effects on Health: II. Antioxidants and Cancer Prevention, American Chemical Society, Washington DC.

Je J.Y.; P.J. Park \& S.K. Kim (2005). Antioxidant activity of a peptide isolated from Alaska pollack (Theragra chalcogramma) frame protein hydrolysate. Food Research International, 38, 45-50.

Je J.Y.; Z.J. Qian; H.G. Byun \& S.K. Kim (2007). Purification and characterization of an antioxidant peptide obtained from tuna backbone protein by enzymatic hydrolysis. Process Biochemistry, 42, 840-846.

Jun, S.Y.; P.J. Park; W. Jung \& S.K. Kim (2004). Purification and characterization of an antioxidative peptide from enzymatic hydrolysate of yellowfin sole (Limanda 
aspera) frame protein. European Food Research and Technology, 219, 20-26.

Kalantzakis, G.; G. Blekas; K. Pegklidou \& D. Boskou (2006). Stability and radicalscavenging activity of heated olive oil and other vegetable oils. European Journal of Lipid Science and Technology, 108, 329-335.

Koochecki, A.; A.R. Thaerian; S.M.A. Ravazi \& A. Bostan (2009). Response surface methodology for optimization of extraction yield, viscosity, hue and emulsion stability of mucilage extracted from Lepiduine perfoliatum seeds. Food Hydrocolloids, 23, 2369-2379.

Korhonen, H. \& A. Pihlanto (2003). Food-derived bioactive peptides-opportunities for designing future foods. Current Pharmaceutical Design, 9, 1297-1308.

Little, T.M. \& F.J. Hills (1978). Agricultural Experimentation: Design and Analysis. John Wiley and Sons, New York, USA.

Misnawi (2003). Influence of Cocoa Polyphenols and Enzyme Reactivation on the Flavor Development of Underfermented Cocoa Beans. PhD thesis. Universiti Putra Malaysia. Serdang, Selangor Darul Ehsan, Malaysia.

Namiki, M. (1990). Antioxidants/antimutagens in food. Critical Review in Food Science and Nutrition, 29, 273-300.

Ovissipour, M.; A.A. Kenari; A. Motamedzadegan; B. Rasco \& R.M. Nazari (2011). Optimization of protein recovery during hydrolysis of yellowfin tuna (Thunnus albacares) visceral proteins. Journal of Aquatic Food Product Technology, 20, 148-159.

Pasupuleti, V.K. \& S. Braun (2010). State of the art manufacturing of protein hydrolysates. Protein Hydrolysates in Biotechnology, 11-32.

Pratt, D.E. (1992). Natural antioxidants from plant material. p. 54-71. In: M.T. Huang, C.T. Ho \& C.Y. Lee (Eds.). Phenolic Compounds in Food and Their Effects on Health: II. Antioxidants and Cancer Prevention, American Chemical Society, Washington DC, USA.

Proestos, C. \& M. Komaitis (2006). Ultrasoundally as sisted extraction of phenolic compounds from aromatic plants: comparison with conventional extraction technics. Journal of Food Quality, 29, 567-582.

Ramarathnam, N.; T. Osawa; H. Ochi \& S. Kawakishi (1995). The contribution of plant food antioxidants to human health. Trends in Food Science and Technology, 6, 75-82.

Rawlings, N.D.; F.R. Morton \& A.J. Barrett (2007). An introduction to peptidases and the MEROPS database. p. 161-179. In: J. Polaina \& A.P. MacCabe (Eds.). Industrial Enzymes-Structure, Function and Applications. Springer, Dordrecth, Netherlands.

Rostagno, M.A.; M. Palma \& C.G. Barroso. (2003). Ultrasound-assisted extraction of soy isoflavones. Journal of Chromatography A, 1012, 119-128.

Shahidi F. \& Y. Zhong (2008). Bioactive peptides. Journal of American Organization of Analytical Chemistry International. 91, 914-931.

Sudarmadji S.; B. Haryono \& Suhardi (1997). Prosedur Analisa untuk Bahan Makanan dan Pertanian. Liberty, Jogjakarta, Indonesia.

Szydłowska-Czerniak; A.K. Trokowski; G. Karlovits \& E. Szłyk (2010). Determination of antioxidant capacity, phenolic acids, and fatty acid composition of rapeseed varieties. Journal of Agricultural and Food Chemistry, 58, 7502-7509.

Wang, J.; B.G. Sun; Y.P. Cao; Y. Tian \& X.H. Li (2008). Optimisation of ultrasound-assisted extraction of phenolic compounds from wheat bran. Food Chemistry, 106, 804-810.

Weisburger, J.H. (2001). Chemopreventive Effects of Cocoa Polyphenols on Chronic Diseases. American Health Foundation, NewYork, USA. 
Wu, W.A.; N.S. Hettiarachchy \& M. Qi (1998). Hydrophobicity, solubility, and emulsifying properties of soy protein peptides prepared by papain modification and ultrafiltration. Journal of American Oil Chemist Society, 75, 845-850.

Wu, H.C.; H.M. Chen \& C.Y. Shiau (2003). Free amino acids and peptides as related to antioxidant properties in protein hydrolysates of mackerel (Scomber austriasicus). Food Research International, 36, 949-957.

Ye, J.; L. Feng; J. Xiong \& Y. Xiong (2011). Ultrasound-assisted extraction of corn carotenoids in ethanol. International Journal of Food Science and Technology, 46, 2131-2136.

Yu, L.; S. Haley; J. Perret; M. Harris; J. Wilson \& M. Qian (2002). Free radical scavenging properties of wheat extracts. Journal of Agriculture and Food Chemistry, $50,1619-1624$.
Zarei, M.; A. Ebrahimpour; A. Abdul-Hamid; F. Anwar \& N. Sari (2012). Production of defatted palm kernel cake protein hydrolysate as a valuable source of natural antioxidants. International Journal of Molecular Sciences, 13, 8097-8111.

Zhang, M.; T.H. Mu; Y.B. Wang \& M.J. Sun (2012). Evaluation of free radical-scavenging activities of sweet potato protein and its hydrolysates as affected by single and combination of enzyme systems. International Journal of Food Science and Technology, 47, 696-702.

$* * 0 * *$ 